\title{
Induction and persistence of pituitary and ovarian activity in the out-of-season lactating dairy goat after a treatment combining a skeleton photoperiod, melatonin and the male effect
}

\author{
P. Chemineau, E. Normant, J. P. Ravault and J. Thimonier \\ I.N.R.A.-Physiologie de la Reproduction, Nouzilly-37380, Monnaie, France
}

\begin{abstract}
Summary. Thirty-two out-of-season Saanen dairy goats were involved in a $2 \times 2$ factorial experiment using (1) extra-light treatment (equivalent to long days) from 18 January to 19 March, at the end of gestation and the onset of lactation and (2) daily melatonin injections (equivalent to short days) from $20 \mathrm{March}$ to 30 June. Hence, there were 4 groups of 8 goats each: CC (control-control), EC (extra-light-control), CM (control-melatonin) and EM (extra-light-melatonin). In each group teasers (males and androgenized females) were introduced on 30 May. Serial blood samples were taken for measurement of LH pulsatility on 30 April and 30 May. Ovarian activity was followed by plasma progesterone assay and laparoscopy. Oestrous behaviour was checked daily from 30 May to 15 July.

The number of LH pulses was not modified by the treatments (extra light or melatonin). Melatonin treatment increased the basal concentration of $\mathrm{LH}$ (Groups CC + $\mathrm{EC}=0.30 \mathrm{ng} / \mathrm{ml}$; Groups $\mathrm{CM}+\mathrm{EM}=0.38 \mathrm{ng} / \mathrm{ml} ; P<0.02)$ and the amplitude of pulses (Groups $\mathrm{CC}+\mathrm{EC}=1.24$; Groups $\mathrm{CM}+\mathrm{EM}=2.44 \mathrm{ng} / \mathrm{ml} ; P<0.02$ ); the highest amplitude was observed for females in Group EM. Melatonin-treated females ovulated earlier after introduction of teasers than did untreated goats (Groups $\mathrm{CM}+\mathrm{EM}=2.3$ days; Groups $\mathrm{CC}+\mathrm{EC}=6.1$ days; $P<0.001)$, but treatments did not modify ovulation rate (mean $2 \cdot 1$ ) or percentage of goats experiencing a short luteal phase. Plasma progesterone concentration during this short luteal phase was higher in melatonin-treated goats (Groups $\mathrm{CM}+\mathrm{EM}=1.61 \mathrm{ng} / \mathrm{ml}$; Groups $\mathrm{CC}+\mathrm{EC}=$ $1.05 \mathrm{ng} / \mathrm{ml} ; P<0.05)$. Ovarian cyclicity persisted longer in Group EM goats than in the other groups: at 2.5 months after introduction of teasers $75 \%$ of the females were still ovulating compared to $12 \%$ in Group CM and none in Groups CC or EC $(P=0.003)$. The number of goats which exhibited oestrus on two or more occasions was higher after melatonin-treatment than in controls $(P=0.013)$.

We conclude that exposure to long days is essential before melatonin treatment to obtain and maintain maximum sexual activity in the out-of-season dairy goat.
\end{abstract}

\section{Introduction}

Photoperiod is the main cue which controls seasonal breeding cycles in many mammals (see reviews: Hansen, 1985; Ortavant et al., 1985). In domestic small ruminants of temperate zones onset of ovarian and oestrous activities in the female generally occur just after the longest days, while cessation of these activities follows the shortest days (see review: Hafez, 1952). In the ewe, experiments in which long (16 h light: $8 \mathrm{~h}$ dark) and short $(8 \mathrm{~h}$ light: $16 \mathrm{~h}$ dark) days are alternated indicate that short days induce sexual activity and that long days inhibit it (Karsch et al., 1984; Thimonier et al., 1985). 
Melatonin secretion by the pineal gland has been identified as the hormonal event which translates neural signals from the eyes into endocrine information. The circadian rhythm of melatonin secretion (elevated melatonin secretion during the dark period) is either inductive of reproductive activity during short days or suppressive during long days (Almeida \& Lincoln, 1982; Bittman \& Karsch, 1984).

However, long-term maintenance under a photoperiod which is initially stimulatory (short days) induces in the ewe a 'refractory state' during which reproductive activity ceases (Thimonier $e t$ al., 1978; Robinson \& Karsch, 1984; see review: Hansen, 1985). A similar refractory state can develop with time to a melatonin pattern which was formerly inductive (Nett \& Niswender, 1982; Karsch et al., 1984). A period of long days seems able to remove the refractory state and to allow a new inductive effect of short days (Yellon \& Foster, 1985).

We suspected that induction and maintenance of oestrus and ovulation in the middle of the anoestrous season by administration of exogenous melatonin might only be possible if the refractory state induced by short days had been previously removed by a phase of long days. In the dairy goat, which is known to be a 'short-day breeder' (Bissonnette, 1941), we tried a combination of long days, to remove the refractory state, and melatonin injections to mimic short days during natural increasing daylengths, in order to induce out-of-season breeding. Based on the demonstration in the ewe that a long day is a day when light is given 16-17 h after dawn (Thimonier et al., 1985), we utilized a skeleton photoperiod to mimic a long day.

A preliminary report of this work has been given in abstract form (Chemineau et al., 1986).

\section{Materials and Methods}

\section{Animals}

Thirty-two females (16 multiparous and 16 nulliparous) of the Saanen dairy breed were involved in the experiment. They were placed in four groups of equal size and similar age, live weight, preceding lactation (multiparous) or dam's lactation (nulliparous) and date of conception. These animals gave birth from 1 February to 18 March, 1985.

All animals received the same feeding regimen composed of barley, oats, soya, beetroot pulp and lucerne hay, quantities of which were adjusted to the physiological state and milk production (INRA, 1978). Six weeks before kidding animals were no longer milked.

\section{Photoperiodic and melatonin treatments}

The experimental design was a $2 \times 2$ factorial; the two factors were: (1) extra-light or no extralight and (2) melatonin or no melatonin. Photoperiodic treatment began on 18 January, 1-2 months before kidding. Before that time all females received a natural photoperiod (latitude $47^{\circ} \mathrm{N}$ ).

Two groups (EM and EC) of 8 females each, were treated with extra-light with or without melatonin and received from 18 January to 19 March the photoperiodic treatment indicated in Fig. 1: dawn was fixed at $05: 30 \mathrm{~h}$, dusk was variable (normal variation) and $2 \mathrm{~h}$ of extra-light were given each day from 16 to $18 \mathrm{~h}$ after dawn. Extra-light was obtained by fluorescent tubes providing 500 lux to the animals. After 19 March all animals were maintained under natural conditions. The two other groups of 8 females each, Groups CC (no extra-light, no melatonin) and CM (no extra-light but + melatonin), were kept in the natural photoperiod.

Melatonin treatment was given from 20 March to 30 June to females in Groups CM and EM; each one received an i.m. injection of $2 \mathrm{mg}$ melatonin (Sigma, P.O. Box 14508, St Louis, MO, U.S.A.), dissolved in ethanol and distilled water (10/90 v/v; Kennaway \& Seamark, 1980). Injections were done daily at 15:00 $\mathrm{h}$. 


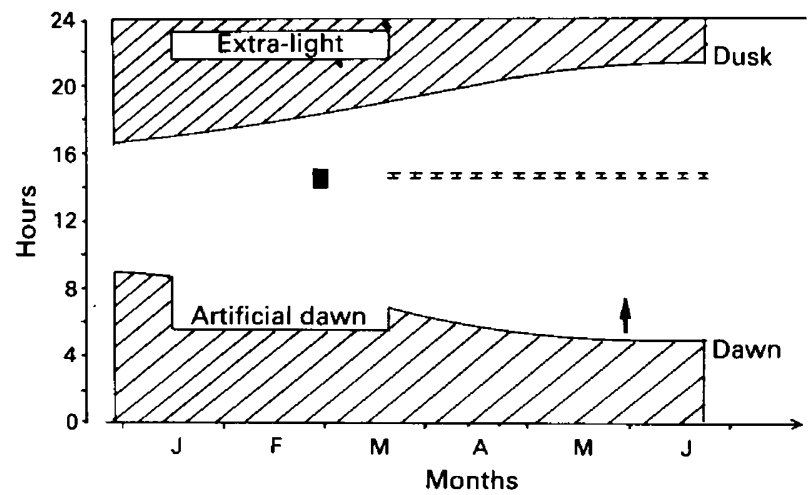

Fig. 1. Experimental schedule: 8 goats received extra-light plus melatonin (Group EM), 8 received only extra-light (Group EC), 8 received only melatonin (Group $\mathrm{CM}$ ) and 8 goats received no treatment (Group CC). $\amalg$ Dark; $\square$ light; $x \leq x$, daily melatonin injections; $\square$ mean date of kiddings; 4 introduction of males.

\section{Stimulus animals for the male effect}

Two additional females were treated with testosterone in oil, as described by Barker \& Bosu (1980). Such a treatment produces sexual behaviour equivalent to that of males during the breeding season. Two intact adult males received the light-melatonin treatment (EM).

Androgenized females and EM males (both referred to as 'teasers'), after a complete separation of $>1$ month, were introduced among the 32 experimental females on 30 May at 12:00 h. Males were removed on 13 June but androgenized females were left until 28 June.

\section{Criteria used to test the efficacy of the different treatments}

Several criteria were used to determine the effect of the different treatments: pituitary activity measured by LH pulsatile secretion, ovarian activity and oestrous activity.

Pituitary activity. Repeated samplings of blood for assessment of pulsatile LH secretion were performed on two separate occasions. The first one was on 30 April (45 days after onset of melatonin treatment) and the second on 30 May. The samples were obtained from 5 representative females in each group of 8 , the same 5 females on both occasions. They were bled from the jugular vein (vacuum tubes: $5 \mathrm{ml}$ ) every $20 \mathrm{~min}$ for $6 \mathrm{~h}$. On 30 May, teasers were introduced in the middle of the sampling period in order to use the 'male effect' as stimulator of the hypothalamo-pituitary activity which could permit detection of eventual group differences.

The assay of LH was performed as described by Pelletier et al. (1982) and modified by Montgomery et al. (1985). This sheep assay has been previously validated for goats (Chemineau $e t$ al., 1982). All tubes were measured in the same assay, and the sensitivity and intra-assay coefficient of variation were respectively $0 \cdot 1 \mathrm{ng} / \mathrm{ml}$ plasma and $12 \%$.

Ovarian and oestrous activities. From 1 May to 3 June plasma progesterone concentrations in twice weekly blood samples were measured by rapid radioimmunoassay (Terqui \& Thimonier, 1974), a procedure which allowed us to distinguish females which were cyclic from those which were anovulatory (Thimonier, 1978).

From 3 June to 28 June plasma progesterone concentrations were measured daily by a quantitative assay slightly modified from that described by Saumande et al. (1985): assays were not performed in duplicate, and immunoprecipitation was accelerated by adding polyethylene glycol and the second antibody at the same time. All tubes were measured in the same assay. Sensitivity was $0.1 \mathrm{ng} / \mathrm{ml}$ and intra-assay coefficients of variation for $1.6 \mathrm{ng} / \mathrm{ml}$ and $7 \cdot 1 \mathrm{ng} / \mathrm{ml} \mathrm{plasma} \mathrm{were}$ 
respectively $19 \%$ and $12 \%$. Such a quantitative assay allowed us to detect the quality of luteal phases induced by the introduction of bucks.

From 28 June to 1 September, plasma progesterone concentrations in samples taken every 10 days were measured as described for those taken from 1 May to 3 June in order to differentiate females which were cyclic and those which were anovulatory.

A laparoscopy was done on all females 14 days after introduction of males. The method used was simplified from that described by Thimonier \& Mauleon (1969). Age of corpora lutea (CL) was estimated from their size and colour (Oldham \& Lindsay, 1980).

Oestrous behaviour was checked twice daily from 30 May to $15 \mathrm{July}$. A prostaglandin analogue (Luprostiol: Intervet, B.P. 235, 49002 Angers cedex, France) was injected intramuscularly about 10 days after oestrus between 30 May and 13 June to avoid conceptions and to permit continued cyclic activity.

\section{Analysis of results}

The definition of an LH pulse was derived from Martin et al. (1983): a pulse was an increase of LH concentration from one sample to the next which exceeded 3 times the basal level and which was followed by a gradual decrease during the two following samples. The amplitude of the $\mathrm{LH}$ pulses was the difference between the basal level (average of the 5 lowest values) and the maximum concentrations reached during pulses during a sampling period.

The dates of ovulation were estimated by combining oestrous behaviour detections (ovulation occurred 24-48 h after the onset of oestrus; Gonzalez-Stagnaro et al., 1984), plasma progesterone concentrations and direct observation of CL by laparoscopy.

Statistical analyses were done by two-way analysis of variance, the two factors being extra-light and melatonin treatments. When no effect of treatment $\mathrm{cr}$ of interaction was detected, mean value for the considered groups was given (for example when no effect of extra-light or interaction was detected, mean values of control and extra-light groups were pooled). The comparisons of percentages between groups were done by calculation of exact probabilities (Dagnelie, 1970).

\section{Results}

\section{LH pulsatility}

The number of $\mathrm{LH}$ pulses (Table 1), before introduction of teasers was identical in the four groups: 0.6 pulses $/ 3 \mathrm{~h} /$ female on 30 April and 0.7 on 30 May.

After introduction of teasers the number of LH pulses increased dramatically in all groups to 2.3 pulses $/ 3 \mathrm{~h} /$ female. No significant effects of the treatments were detected in the number of pulses. However, the average number of pulses was $1.8 / 3 \mathrm{~h} / \mathrm{female}$ in Group CC compared to 2.5 in the three other groups (CM, EC and EM).

The basal concentration of $L H$ (Table 1 ) on 30 April was significantly affected by melatonin treatment: the value was higher in the melatonin-treated females than in the untreated ones (Groups $\mathrm{CM}+\mathrm{EM}=0.38 \mathrm{ng} / \mathrm{ml}$; Groups $\mathrm{CC}+\mathrm{EC}=0.30 \mathrm{ng} / \mathrm{ml} ; P<0.02$ ). On 30 May (whole period, before and after teasers) no significant effects of treatments were detected on the basal concentration of $\mathrm{LH}$.

The amplitude of LH pulses (Fig. 2) on 30 April was higher in the females receiving extra-light (Groups EC + EM: $0.72 \mathrm{ng} / \mathrm{ml}$ ), but not statistically significantly different from Groups $\mathrm{CC}+\mathrm{CM}(0 \cdot 44 \mathrm{ng} / \mathrm{ml} ; \mathrm{F}=2 \cdot 36)$. On 30 May (whole period) the mean amplitude of the LH pulses in the melatonin-treated females was twice that of the untreated goats (Groups $\mathrm{CM}+\mathrm{EM}=$ $2.44 \mathrm{ng} / \mathrm{ml}$; Groups $\mathrm{CC}+\mathrm{EC}=1.24 \mathrm{ng} / \mathrm{ml} ; P<0.02$ ); the mean amplitudes (s.e.m.) for the four groups were, CC: $1 \cdot 19(0 \cdot 54)$, EC: $1 \cdot 29(0 \cdot 16), \mathrm{CM}: 2 \cdot 13(0 \cdot 46), \mathrm{EM}: 2 \cdot 75(0 \cdot 65)$. 
Table 1. Total number of LH pulses and mean ( \pm s.d. for 5 females/group) basal plasma LH concentration in samples obtained every $20 \mathrm{~min}$ from intact dairy goats during two 6 -h periods

\begin{tabular}{|c|c|c|c|c|c|}
\hline \multirow[b]{3}{*}{ Group } & \multicolumn{3}{|c|}{$\begin{array}{l}\text { Total no. of LH pulses } \\
\text { (in } 5 \text { goats/group) }\end{array}$} & \multicolumn{2}{|c|}{$\begin{array}{l}\text { Basal LH conc. } \\
\text { (ng/ml plasma) }\end{array}$} \\
\hline & \multirow{2}{*}{$\underset{\mathrm{April}}{6 \mathrm{~h}} 30$} & \multicolumn{2}{|c|}{ May 30} & \multirow[t]{2}{*}{ April 30} & \multirow[t]{2}{*}{ May 30} \\
\hline & & $\begin{array}{l}\text { Before male } \\
\quad 3 \mathrm{~h}\end{array}$ & $\begin{array}{l}\text { After male } \\
\quad 3 \mathrm{~h}\end{array}$ & & \\
\hline $\mathrm{CC}$ (control-control) & 4 & 3 & 9 & $\begin{array}{r}0.30 \\
\pm 0.04\end{array}$ & $\begin{array}{r}0.32 \\
\pm 0.04\end{array}$ \\
\hline EC (extra-light-control) & 7 & 3 & 12 & $\begin{array}{r}0.31 \\
\pm 0.02\end{array}$ & $\begin{array}{r}0.30 \\
\pm 0.01\end{array}$ \\
\hline $\mathrm{CM}$ (control-melatonin) & 5 & 3 & 13 & $\begin{array}{r}0.35 \\
\pm 0.09\end{array}$ & $\begin{array}{r}0.33 \\
\pm 0.06\end{array}$ \\
\hline EM (extra-light-melatonin) & 7 & 4 & 12 & $\begin{array}{r}0.42 \\
\pm 0.09\end{array}$ & $\begin{array}{r}0.31 \\
\pm 0.02\end{array}$ \\
\hline
\end{tabular}

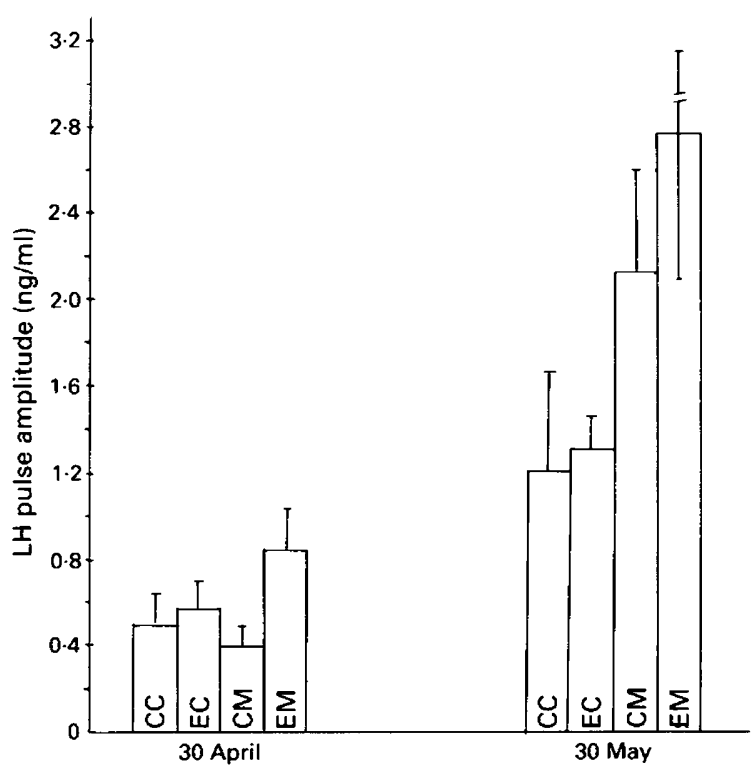

Fig. 2. Mean ( \pm s.e.m., for 5 females/group) amplitude of LH pulses in samples obtained every $20 \mathrm{~min}$ from intact out-of-season dairy goats during two 6-h periods.

For the number of LH pulses, the basal concentration and the amplitude of LH pulses, the interactions between light and melatonin treatments were not significant.

\section{Ovarian activity}

No ovulation was detected before the introduction of teasers in any group. Introduction of teasers induced ovulations in almost all females (31/32). However, the melatonin treatment affected significantly the interval between introduction of teasers and first ovulation (Groups $\mathrm{CM}+\mathrm{EM}=$ $2.3 \pm 0.8$ days; Groups $\mathrm{CC}+\mathrm{EC}=6.1 \pm 2.9$ days; $P<0.001)$. The light treatment did not affect time of ovulation, and the interaction between treatments was not significant. 
Table 2. Number of goats (8/group) displaying 1,2 or 3 successive male-induced ovulations and ovarian activity 2.5 months after introduction of males in out-ofseason dairy goats

\begin{tabular}{lcccc}
\hline Group & $\begin{array}{c}\text { 1st } \\
\text { ovulation }\end{array}$ & $\begin{array}{c}\text { 2nd } \\
\text { ovulation }\end{array}$ & $\begin{array}{c}\text { 3rd } \\
\text { ovulation }\end{array}$ & $\begin{array}{c}\text { Ovarian activity } \\
2 \cdot 5 \text { months after } \\
\text { introduction of } \\
\text { teasers }\end{array}$ \\
\hline CC (control-control) & 8 & 6 & $3^{\mathrm{a}}$ & $0^{\mathrm{c}}$ \\
EC (extra-light-control) & 8 & 5 & $4^{\mathrm{a}}$ & $0^{\mathrm{c}}$ \\
CM (control-melatonin) & 7 & 7 & $5^{\mathrm{a}}$ & $1^{\mathrm{c}}$ \\
EM (extra-light-melatonin) & 8 & 8 & $8^{\mathrm{b}}$ & $6^{\mathrm{d}}$ \\
\hline
\end{tabular}

Values with different superscripts are significantly different: a vs b, $P<0.05 ; \mathrm{c} v s \mathrm{~d}, P<0.003$.

Ovulation rate was not significantly modified by any of the treatments; mean ovulation rates were $2 \cdot 12,1 \cdot 87,2 \cdot 14$ and $2 \cdot 25$ in Groups CC, EC, CM and EM respectively. The majority of goats in each group displayed a short luteal phase after induced ovulation; the percentages of goats with a short cycle were respectively $87 \%$ in Group CC, $75 \%$ in Group EC, $57 \%$ in Group CM and $75 \%$ in Group EM; no significant effects of treatments on these percentages were detected. For the females experiencing a short luteal phase after the induced ovulation, the maximal concentration of plasma progesterone during this cycle was significantly higher in melatonin-treated females than in the other goats (Groups CM $+\mathrm{EM}=1.61 \pm 0.86 \mathrm{ng} / \mathrm{ml}$; Groups CC $+\mathrm{EC}=1.05 \pm 0.40 \mathrm{ng} / \mathrm{ml}$; $P<0.05$ ).

Ovarian cyclicity persisted longer in the females in Group EM: $100 \%$ of them displayed 3 successive cycles compared to $<60 \%$ in the three other groups $(P=0.038)$, and 2.5 months after introduction of teasers (i.e. mid-August) $75 \%$ of Group EM goats still ovulated compared to $12 \%$ in Group CM $(P=0.003)$ and none in Groups CC and EC (Table 2).

\section{Oestrous behaviour}

The number of females showing oestrous behaviour at the first induced ovulation was not significantly higher in melatonin-treated females (Groups CM + EM 5 females; Groups CC + EC 2 females; $P=0 \cdot 15$ ). The second ovulation was always associated with an oestrus. The percentage of females which showed at least two oestrous periods was significantly higher for melatonintreated females than for control goats $(P=0.013): 8 / 8$ in Group EM; $5 / 8$ in Group EC; $5 / 8$ in Group CM and 2/8 in Group CC.

\section{Discussion}

The combination of a skeleton photoperiod and melatonin treatment affected the anoestrous intensity of the female goats as pituitary LH activity was increased, ovarian and oestrous responses to introduction of males were improved and ovarian cyclicity persisted for more than 2 months. Indeed, the intensity of the response to the male effect was not identical in the four groups: the amplitude of LH pulses was two-fold higher in melatonin-treated females than in control goats. However, melatonin treatment was more effective when females had previously received the light treatment. The mechanisms which could explain such an effect of melatonin on LH pulse amplitude remain unknown. In the ewe melatonin does not seem to affect directly the pituitary response to GnRH pulses (Rodway \& Swift, 1983). Consequently, it could be affecting GnRH pulse amplitude itself.

Stimulation by the teasers was effective not only in increasing LH pituitary activity, but also in inducing ovulations, because $97 \%$ of the goats ovulated within 12 days after introduction of males. 
However, timing of ovulations and expression of oestrous behaviour differed between groups, with melatonin-treated females ovulating for the first time 4 days earlier than the untreated goats. Most of the animals in all treatment groups showed a short luteal phase after the first ovulation as it has been described previously in the goat (Ott et al., 1980; Chemineau, 1983; Chemineau et al., 1984). The higher level of circulating progesterone observed in melatonin-treated females could be due to the higher ovulation rate in these goats. However, the low number of females used impairs any significant difference between groups in this respect.

The combination of long days and melatonin was therefore able to increase $\mathrm{LH}$ secretion, hasten ovulation time, increase progesterone secretion and elicit more oestrous behaviour. In addition, this treatment was active in maintaining ovarian cyclicity. Williams (1985) has indicated that such a treatment maintained oestrous cyclicity in ewes. In the goats in Group EM the persistence of ovarian activity for 2.5 months demonstrated the additive effects of long day treatment and melatonin injections. This persistence of ovarian activity suggests that the does in Group EM are reacting as though it were September-October, the usual time of sexual activity in the goat, rather than June. The physiological mechanisms involved in the control and maintenance of ovarian cyclicity are therefore functioning, apparently with the same efficiency as during the normal sexual season. The treatment with extra-light and melatonin has decreased the sensitivity to the oestradiol negative feed-back which is thought to be responsible for the seasonal decrease in LH secretion (Karsch et al., 1984). The photoperiodic treatment used, which mimics long days, was able to reverse the refractory state induced by the short days to which the animals were exposed during the 4 months preceding the present experiment, and which is thought to be responsible for anoestrus (Robinson \& Karsch, 1984; Kennaway \& Gilmore, 1984). The goats were then able to respond to the light shift between long days (extra-light) and short days (melatonin). In the Group CM females which passed from increasing daylengths (on 19 March daylength was $13 \mathrm{~h}$ ) to short days $(8 \mathrm{~h}$, simulated by melatonin treatment), the period of increasing daylengths from January to March was not sufficient to reverse the refractory state: the cyclicity obtained after exposure to teasers was not maintained. In the ewe lamb it is also necessary to do a priming with long days to remove refractoriness to short days and to obtain a new stimulatory effect of short days (Yellon \& Foster, 1985). The physiological mechanisms involved in the appearance and disappearance of refractoriness to short days remain unknown; Malpaux et al. (1985) have shown that it is probably a post-pineal processing of the melatonin signal rather than a disruption of the secretory pattern of melatonin in the ewe.

The conclusions drawn from our experiment are that: (1) prior exposure to a period of 'long days' can significantly enhance the 'short-day' effect of melatonin treatment on reproduction by increasing LH secretion, advancing ovulation and extending the breeding season; and (2) the induction and maintenance of ovarian cyclicity were possible soon after kidding in out-of-season dairy goats maintained in an open fold by using a combination of extra-light, melatonin injections and the male effect.

We thank B. Mirman and all the technicians of the experimental farm of Brouessy for their help during the experiment; and Dr J. Pelletier, A. Daveau, F. Maurice and D. Andre for their help with the LH and progesterone assays.

\section{References}

Almeida, O.F.X. \& Lincoln, G.A. (1982) Photoperiodic regulation of reproductive activity in the ram: evidence for the involvement of circadian rhythms in melatonin and prolactin secretion. Biol. Reprod. 27, 1062-1075.
Barker, C.A.V. \& Bosu, W.T.K. (1980) Studies on experimental androgenized females: goats. Proc. 9 th Int. Congr. Anim. Reprod. \& A.I., Madrid 2, 593-599.

Bissonnette, T.H. (1941) Experimental modification of breeding cycles in goats. Physiol. Zool. 14, 379-383. 
Bittman, E.L. \& Karsch, F.J. (1984) Nightly duration of pineal melatonin secretion determines the reproductive response to inhibitory day length in the ewe. Biol. Reprod. 30, 585-593.

Chemineau, P. (1983) Effect on oestrus and ovulation of exposing creole goats to the male at three times of the year. J. Reprod. Fert. 67, 65-72.

Chemineau, P., Gauthier, D., Poirier, J.C. \& Saumande, J. (1982) Plasma levels of LH, FSH, prolactin, oestradiol $17 \beta$ and progesterone during natural and induced oestrus in the dairy goat. Theriogenology 17, 313-323.

Chemineau, P., Poulin, N. \& Cognié, Y. (1984) Sécrétion de progestérone au cours du cycle induit par l'introduction du mâle chez la chèvre créole en anoestrus: effets de la saison. Reprod. Nutr. Dévelop. 24, 557-561.

Chemineau, P., Normant, E., Ravault, J.P. \& Thimonier, J. (1986) Evidence that skeleton photoperiod, melatonin and male effect could affect pituitary and ovarian activity in the out-of-season lactating dairy goat. Biol. Reprod. 34, Suppl. 1, 378 Abstr.

Dagnelie, P. (1970) Théorie et Méthodes Statistiques. Vol. 2, 451 pp. Presses Agronomiques de Gembloux, Gembloux.

Gonzalez-Stagnaro, C., Pelletier, J., Cognie, Y., Locatelli, A., Baril, G. \& Corteel, J.M. (1984) Descarga preovulatoria de $\mathrm{LH}$ y momento de ovulacion en cabras lecheras durante el celo natural o inducido por via hormonal. Proc. 10th Int. Congr. Anim. Reprod. \& A.I., Urbana-Champaign 2, paper No. 10.

Hafez, E.S.E. (1952) Studies on the breeding season and reproduction of the ewe. J. agric. Sci., Camb. 42, $189-265$.

Hansen, P.J. (1985) Photoperiodic regulation of reproduction in mammals breeding during long days versus mammals breeding during short days. Anim. Reprod. Sci. 9, 301-315.

INRA (1978) Alimentation des Ruminants. I.N.R.A. Publications, Versailles.

Karsch, F.J., Bittman, E.L., Foster, D.L., Goodman, R.L., Legan, S.J. \& Robinson, J.E. (1984) Neuroendocrine basis of seasonal reproduction. Recent Prog. Horm. Res. 36, 1-43.

Kennaway, D.J. \& Gilmore, T.A. (1984) Effects of melatonin implants in ewe lambs. J. Reprod. Feri. 70, $39-45$.

Kennaway, D.J. \& Seamark, R.F. (1980) Circulating levels of melatonin following its oral administration or subcutaneous injection in sheep and goats. Aust. $J$. Biol. Sci. 33, 349-353.

Malpaux, B., Robinson, J.E. \& Karsch, F.J. (1985) Is refractoriness of the ewe to short photoperiod caused by a disruption of the secretory pattern of melatonin? Biol. Reprod. 32, Suppl. 1, Abstr. 42.

Martin, G.B., Scaramuzzi, R.J. \& Henstridge, J.D. (1983) Effects of oestradiol, progesterone and androstenedione on the pulsatile secretion of luteinizing hormone in ovariectomized ewes during spring and autumn. J. Endocr. 96, 181-193.

Montgomery, G.W., Martin, G.B. \& Pelletier, J. (1985) Changes in pulsatile LH secretion after ovariectomy in Ile-de-France ewes in two seasons. $J$. Reprod. Fert. 73, 173-183.
Nett, T.M. \& Niswender, G.D. (1982) Influence of exogenous melatonin on seasonality of reproduction in sheep. Theriogenology 17, 645-652.

Oldham, C.M. \& Lindsay, D.R. (1980) Laparoscopy in the ewe: a photographic record of the ovarian activity of ewes experiencing normal or abnormal oestrous cycles. Anim. Reprod. Sci. 3, $119-124$.

Ortavant, R., Pelletier, J., Ravault, J.P., Thimonier, J. \& Volland-Nail, P. (1985) Photoperiod: main proximal and distal factor of the circannual cycle of reproduction in farm mammals. Oxford Rev. Reprod. Biol. 7, 305-345.

Ott, R.S., Nelson, D.R. \& Hixon, J.E. (1980) Effect of presence of the male on initiation of oestrous cycle activity of goats. Theriogenology 13, 183-190.

Pelletier, J., Garnier, D.H., de Reviers, M.M., Terqui, M. \& Ortavant, R. (1982) Seasonal variation in LH and testosterone release in rams of two breeds. J. Reprod. Fert. 64, 341-346.

Robinson, J.E. \& Karsch, F.J. (1984) Refractoriness to inductive day lengths terminates the breeding season of the suffolk ewe. Biol. Reprod. 31, 656-663.

Rodway, R.G. \& Swift, A.D. (1983) Melatonin and the pituitary response to $\mathrm{GnRH}$ in prepubertal and adult ewes. Horm. Metab. Res. 15, 349-351.

Saumande, J., Tamboura, D. \& Chupin, D. (1985) Changes in milk and plasma concentrations of progesterone in cows after treatment to induce superovulation and their relationships with number of ovulations and embryos collected. Theriogenology 23, 719-731.

Terqui, M. \& Thimonier, J. (1974) Nouvelle méthode radioimmunologique rapide pour l'estimation du niveau de progestérone plasmatique. Application pour le diagnostic précoce de la gestation chez la brebis et chez la chèvre. C. r. hebd. Séanc. Acad. Sci., Paris D 279, 1109-1112.

Thimonier, J. (1978) L'activité ovarienne chez les bovins. Moyens d'étude et facteurs de variation. Annls Méd. vét. 122, $8 \mathrm{I}-92$.

Thimonier, J. \& Mauleon, P. (1969) Variations saisonnières du comportement d'oestrus et des activités ovarienne et hypophysaire chez les ovins. Annls Biol. anim. Biochim. Biophys. 9, 233-250.

Thimonier, J., Ravault, J.P. \& Ortavant, R. (1978) Plasma prolactin variations and cyclic ovarian activity in ewes submitted to different light regimens. Annls Biol. anim. Biochim. Biophys. 18, 1229-1235.

Thimonier, J., Brieu, V., Ortavant, R. \& Pelletier, J. (1985) Daylength measurement in sheep. Biol. Reprod. 32, Suppl. 1, Abstr. 36.

Williams, H.L.L. (1985) The use of melatonin to initiate breeding activity in photoperiodic breeds of sheep. Proc. 36th A. Meeting, E.A.A.P., Kallithea 2, 240-241.

Yellon, S.M. \& Foster, D.L. (1985) Alternate photoperiods time puberty in the female lamb. Endocrinology 116, 2090-2097. 